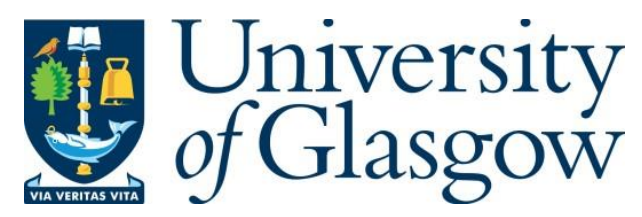

Ferrie, J. and Hosie, A. (2018) Methodological challenges in developing an evidence base, and realizing rights. International Journal of Human Rights, 22(1), pp. 5-21.

There may be differences between this version and the published version. You are advised to consult the publisher's version if you wish to cite from it.

http://eprints.gla.ac.uk/149436/

Deposited on: 10 October 2017

Enlighten - Research publications by members of the University of Glasgow http://eprints.gla.ac.uk 
Methodological challenges in developing an evidence base, and realizing rights

Jo Ferrie* and Alison Hosie**

* Sociology, University of Glasgow, UK

** Scottish Human Rights Commission

Jo Ferrie, Room 1001, Adam Smith Building, 40 Bute Gardens, University of Glasgow, Glasgow, UK, G12 8RT. Jo.Ferrie@ glasgow.ac.uk 


\section{Methodological challenges in developing an evidence base, and realizing rights}

This paper focuses on the methodological challenges for a small nation, with a view to reforming and realizing human rights. The paper begins with a review of traditional measures that seek to capture comparative data and the limitation of indicators both generally and as a tool for capturing violations in Scotland. Capturing violations, particularly those that are hidden (because they happen in private spaces or to those without power or status) are necessary to clearly understand what reform is required. This creates methodological challenges in collecting data that is perhaps not understood within a human rights framework and so is not reported adequately. The paper will focus on national action plans (NAP), using the example of Scotland's NAP (SNAP) ${ }^{1}$ as vital for creating a space allowing for data collection and solution generation, shared by those who experience violations and those with the power to challenge. Diffusing responsibility for action to Rights Holders and Duty Bearers engaged in creating the space facilitates reform. Further this approach can lend legitimacy to those who are violated, because they appear in spaces where their experiences are recognized within a human rights framework. This evidence can be used to demonstrate the prevalence of rights violations in a small nation, and thus can feed into debates about the need for human rights legislation and measures that go beyond comparative indicators. It also highlights that a State must be committed to reform regardless of methodology used if it is to realize rights.

Keywords: methodology; indicators; qualitative; collaborative; participatory

\section{Introduction}

The central purpose of this paper, is to set out the process by which the Scottish Human Rights Commission (referred to now as Commission) developed its evidence base; explain why it took the methodological approach that it did and to explore a number of the challenges that were faced during this process. In doing so, the paper aims to highlight in particular the value of this methodological approach (despite its challenges) for countries which have, on an international comparative scale, seemingly good 
national human rights records.

Within the UN's network of States, statistics have dominated as the best way to produce comparative data. The paper will outline some of the limitations of this approach. The paper first considers why academic communities in particular, have found finding alternative approaches to measuring rights so challenging. The dominance of legal work; the slow but gradual emergence of sociological and policy focus on rights; and the lack of a strong theoretical base for understanding the realization of rights are considered as barriers to efforts to enable right holders to assert their rights.

The skills of social scientists are key to generating evidence to enable a country like Scotland to identify infringements and then tackle them. Debates around measuring rights have (perhaps rightly) focused heavily on evidencing rights infringements at the macro level for example, establishing responsibility for genocide or state sanctioned mass torture. Such publicly performed infringements that have affected millions require the quantified approach. It allows direct comparison with other nation states but also comparison within a state year on year allowing evidence to emerge around the impact of an intervention (a new democratically elected Government for example). One issue with this approach though, is that small peaceful nations such as Scotland appear to not be infringing rights, and as this isn't the case, measures beyond such macro-measures are required.

The paper then sets out how the Commission took a human rights based approach to its research, including explaining its predominantly (although not exclusively) qualitative mixed-method approach which made use of primary and secondary data sources; and 
the FAIR ${ }^{2}$ analysis framework that facilitated all data to be analyzed through a human rights lens.

The penultimate section of the paper sets of the key advantages and challenges raised by taking a predominantly qualitative approach, in particular the benefit of relationship building with very marginalised communities that occurred as a by-product of the participative phase of data collection, as well as the difficulty of keeping this type of evidence base current enough to be fit for purpose.

The paper concludes by highlighting the transferable lessons for others undertaking a similar process. It also highlights the current challenge facing the Scottish Human Rights Commission moving forward, in order to address the limitations of their original process and to further enhance and improve the types of data used in future to measure progress in existing areas and identify new areas of concern.

\section{Measuring Human Rights Violations: Indicators}

In order to generate comparative data that allows direct comparison between Nation States, the UN and its Offices have developed Indicators ${ }^{3}$. A form of quantitative measure, they work to capture incidences of violations. Not all possible violations are recorded and agreement is generally met around which indicators carry the most relevance in most States, and act as the best 'proxy' measure. That is, that they indicate not just prevalence of one particular violation, but they represent that other, related violations are probably going on too. 
Indicators are often employed as a technology of governance in situations where lines of authority are unclear, laws is soft rather than hard, jurisdiction is ambiguous and governance requires negotiates among sovereign nations states. ${ }^{4}$

Countries are ranked on their performances with 'shame' the vehicle for improving status on the list ${ }^{5,6}$. Energy spent on audit and improvement relative to the list may distract from reform for the sake of it. For example, motivation may extend only so far as to note be in the bottom quartile with those in the middle, satisfied to remain.

In order to be comparative, indicators are reductionist, they are 'a distilled measure of a concept. ${ }^{7}$ They are further defined as:

It is the simplification of information, the extraction and classification of some diagnostic element out of the buzzing array of particular features of the social world, that is the hallmark of indicators. ${ }^{8}$

And hence is apposite to holistic qualitative data. Essentialism risks corruption of meaning. Data is generally collected as the grassroots of any phenomenon engaging directly with those impacted. To communicate this 'data' to an organization or management level ${ }^{9}$, it is reduced and manipulated which if not done well, or not understood by the consumer of that manipulation is a form of data corruption. If the elite recipients of that manipulation are disconnected from those whom were measured, they are unable to 'read' the data, or to challenge the corruption. And emerging reform, though it may be well-intentioned, it unlikely to impact appropriately.

Further, such corruptions are not random, but politically motivated representing the concerns of a society ${ }^{10}$. For example, the measurement of gender, once seen as biologically determined is now, increasingly understood as fluid, though UK state measurements continue to attempt categorization ${ }^{11}$. Quantitative measurement uses the 
alibi of objectivity, claiming that it transcends power and political biases that work at the social level. However quantification is produced by power imbalances, the reduction to two genders marginalised many from meaningful representation. Measures and indicators ultimately are selected by the elite and privileged and perpetuate their interests. $^{12,13,14}$

While we assume that they describe the world, they actually construct the world. They are neither inherently good nor inherently bad as modes of governance but contribute to the ways in which the world is understood and decisions are made in the global arena. ${ }^{15}$

Indicators can perform different functions. As stated they can measure relative performance. Or they measure, longitudinally, progress. Further they can be used in different ways: to assess the robust nature of government policies or NGO initiatives; as an advocacy tool to encourage reform; or to shame where performance is poor. ${ }^{16}$ Moving forward Scotland can decide how it uses indicators, to scientifically measure (passive); to encourage change (active) or to shame (little evidence about the productivity of this approach).

Their use perpetuates because they remain our best tool for realizing rights, particularly if our scope is Global. Still we should be clear that they are not a perfect tool, specificity is a myth, the indicators are not precise or accurate for the base date is often incomplete and ambiguous measures contaminate interpretations.

Indicators don't just remove context. They also move us towards certain ways of using the data. Visualisations of composite indicators, for example, that rank countries on a measure (The US State Department's Trafficking in Persons Reports ${ }^{17}$ is a key example ${ }^{18}$ ) represent findings on global colour-coded maps. Such a visualization is 
reminiscent of imperial maps of the $19^{\text {th }}$ century showing European colonization of 'territories'. The maps continue to imply the superiority of the West, of the UK and other former 'invaders'. As an aid to reform, does this engage sufficiently with nations victim to imperialism in the past. Does it blame where perhaps it could incentivize investment in reform? For such maps could have existed 150 years ago to celebrate slavery and ownership.

\section{Evidence required to persuade the public that human rights are vital and relevant to them}

Latour ${ }^{19}$ moves this argument towards the collective production of 'facts' and the collective interpretation of them showing that they never truly exist in an objective space, but are constantly 'shifting' as meaning is made of them. The use of indicators in achieving change - their persuasiveness - is indeed evidence of such shifts. Persuading States to take action is one part of the puzzle. A nation that aims to realize rights must engage with a public apathy towards their value, and a prevalent assumption that rights are for 'others', an attitude generally due to media over-representation of stories about claims by prisoners and migrants. ${ }^{20}$ For reform to happen, it is essential to persuade the public that violations happen and that human rights legislation is vital, in Scotland, and worldwide.

Using Latour's insight ${ }^{21}$ into knowledge needing to be persuasive brings us to a notable challenge in Scotland: persuading people (everyone who lives in Scotland) that human rights violations happen here. Thus knowledge about violations has to be robust and convincing to persuade change. 
It is an easy job if you want to convince a few people of something that is almost obvious; it is much harder if you wish to convince a large number of people of something very remote from or even contrary to their current beliefs. ${ }^{22}$

\section{Capturing hidden violations}

\section{Input from social sciences: Theory \& Method}

Though somewhat separated from 'normal folk' by layers of privilege given by their advanced education (and often relating also to gender, class, race and other characteristics that have permitted them to exercise their 'expert' voice) academics are able to effectively advance the enablement of rights holders to assert their rights.

One major contribution that can be made is the development of a robust knowledge base, that allows NHRIs and other stakeholders to identify areas of priority, and to understand the cause and potential solution to socially constructed matters. As well as empirical skills, we can draw on theory to frame this research within an historical context of power and politics, to ensure the data produced is meaningful. There is a lack of a theoretical base for understanding rights infringements. ${ }^{23}$ The social sciences traditionally draw on Marx, Weber \& Durkheim ${ }^{24}$, great minds but working before human rights were conceptualized in their modern form in response to the Holocaust and founding of the United Nations. Returning to these fathers of theory affords little insight into how rights can be realized. Of course other lesser known theorists from the $20^{\text {th }}$ century (found if we move beyond the 'norm' of male, white theorists) is possible of course and the work of Walby around citizenship, ${ }^{25}$ Fraser around redistribution ${ }^{26}$ and Nussbaum around rights of disabled people ${ }^{27}$ are valuable, but still, for various reasons, have not penetrated the social theory cannon. Here explanations are considered 
for why certain groups of people fall outside of rights frameworks and it is perhaps because their concern is with marginalised groups, rather than those traditionally fully recognized as citizens ${ }^{28}$ that have limited their advancement into public awareness. ${ }^{29}$

The awakening of rights as a worthy and important focus for social scientists is growing. While the theoretical foundation may be limited, this gives sociologists and social policists an opportunity to generate strong, robust, valid empirical research that can inform theory and set up a new framework that moves beyond describing oppression, and is useful to rights holders.

Thinking specifically about Scotland and the UK, but with resonance for the rest of the Globe, there has been greater funding available from national research councils for equality research perhaps because of work ${ }^{30,31}$ done to effectively measure progress in achieving equality. In terms of helping us realize rights, this fails on two key points. First, equality is achieved if groups of people are treated equally badly and so equality does not inherently trigger progress, whereas, human rights utilizes a 'threshold' ${ }^{32}$ to allow a minimal standard for all. Secondly it ignores concepts integral to human rights such as dignity and autonomy. ${ }^{33}$

While still an advancement, and while recognizing the incredibly high quality work notably by Walby ${ }^{34}$ and Burchardt \& Vizard, ${ }^{35}$ this work has contributed to a preoccupation with how to produce quantitative data that allows comparisons across space and time, which has thus dominated methodological discussions within the wider academic literature. Again, not to suggest that this work is not massively useful, it does 
have some limitations that need to be recognized and resolved by introducing more methodological tools.

Moving to other forms of research (i.e. qualitative) also moves away from achieving cross-country comparisons but is absolutely essential in order to understand how rights are being actualised, what rights infringements exist, whether they are institutionally triggered (implicating the State and its policies) or more locally triggered (but perhaps connected to social constructions such as patriarchy).

Further to begin to 'fix' society, to challenge those that infringe the rights of others, we must gain a clear idea of what the solution is for each individual. A qualitative analysis of a number of individual responses allows a much more informed and realizable strategy. ${ }^{36,37}$ In the case of state-sanctioned torture, this may not be useful. But when engaging with Economic, Social and Cultural Rights $(\mathrm{ESC})^{38}$ or with experiences low on the global hierarchies (in countries like Scotland), or with rights that are infringed in more personal places such as violence against women or disabled people ${ }^{39}$ it becomes vital.

\section{Participatory \& Collaborative Approaches:}

There is evidence that alternative forms of knowledge based on collaborative, participatory working can co-produce change ${ }^{40}$ Here collective action focuses on finding solutions and instigating change rather than getting lost in defining the problem, apportioning blame or measuring for the sake measurement. Knowledge exchange is a key principle. Those operating at the lower end of hierarchical status can feed in ideas into a shared space where those operating at the higher end can feed in constraints or 
resource implications until a consensus around action is met. Thus everyone is assumed to be, and enabled to operate as an expert. Key to this approach working is that the shared space operates outside of traditional hierarchies. ${ }^{41}$ Though these methods are normally utilised in smaller community based partnerships ${ }^{42}$ the principle can be applied to any community including a small European nation led by elite politicians, academics, service providers and legal experts.

Such drives for change can intersect with a human rights framework. Writing about gendered violence, Merry ${ }^{43}$ argues that such a framework sees the state as responsible for protecting the human rights of women, and thus should be fundamentally concerned with gendered violence. Thus it becomes the concern of the state, rather than the (sole) concern of criminal justice organizations. Duty bearers beyond criminal justice have equal responsibility, in the name of the State, to protect these rights. And in diffusing responsibility, ${ }^{44}$ the framework starts to move away from the hierarchical model that underpins indicator measures. Victims of gendered violence, like all women are in a relationship with the state and should be able to impact on any process to challenge violations of their human rights. Further this approach should enable varying experiences of gendered violence to be challenged as human rights violations. The OHCHR (Office of the High Commissioner for Human Rights) ${ }^{45}$ outlined five broad 'illustrations' of gendered violence:

- Sexual and reproductive health and harmful traditional practices

- Domestic violence

- Violence at work, forced labour and trafficking

- Community violence and abuse by law enforcement officials

- Violence and (post-)conflict and emergency situations Universal Declaration of Human Rights, Articles 1-5 and $16^{46}$ 
Thus this approach can reach private spaces, spaces where women have no power, spaces where women's citizenship is undermined. Critically women can now be instrumental in defining how their rights are violated and can comprehensively demonstrate the violations they suffer.

To learn from this a nation that does not appear as having human rights issues, can through participatory and collaborative investigation and responsibility, both uncover violations and disseminate this evidence to persuade its public that violations do happen and that human rights frameworks are vital.

\section{Exploring human rights in Scotland: Creating a Baseline}

Scotland hosts the Scottish Human Rights Commission, which became fully operational on December 10th 2008, created by a legislative Act of the Scottish Parliament in 2006. ${ }^{47}$ The Commission is an independent public body, accountable to the people of Scotland through the Scottish Parliament, with a broad remit to promote and protect human rights for everyone in Scotland. One of the first activities of the Commission was to better understand what the key human rights issues were in Scotland in order that the work it would undertake in the coming years would be evidence-based. The evidence base was developed in order to:

- Enable the Commission to develop its strategic priorities and work plan;

- Engage with proposed changes and developments in law and policy;

- Respond to policy consultations and parliamentary petitions;

- Critique national progress via treaty body review mechanisms and provide the evidence base to enable civil society to do the same;

- Provide the necessary evidence base to develop a National Action Plan for human rights as promoted by the Vienna Declaration of $1993 .{ }^{48}$ 


\section{SNAP as a collaborative programme}

From the commencement of its operational work the Commission has aimed to 'walk the talk' with regard to how it expects other organisations to approach their work. For the Commission, this has meant taking a Human Rights Based Approach (HRBA) in all that it does. The HRBA was first developed in relation to international development processes and more recently it has been applied to public services, as well as business practices, around the world. Essentially a HRBA helps to integrate the norms, standards and principles of the international human rights system into everyday policy and practice and it can be applied to all areas of public life that affect human rights.

The Commission's working definition of a HRBA is: "giving people greater opportunity to participate in shaping the laws, policies and practices that impact on their human rights; increasing the ability of those with responsibility for fulfilling rights to recognize and respect those rights; and making sure they can be held to account. It also means ensuring non-discrimination, equality and the prioritization of the most marginalised." 49 Therefore, in creating the project plan to develop the evidence base, the PANEL (Participation, Accountability, Non-Discrimination \& Equality, Empowerment \& Legality) principles were embedded within the methodological process from the outset. The research process sought out to engage and empower rights-holders, in particular those who tend to be marginalised and whose voices are less often heard in mainstream debates surrounding human rights.

The research also had to go beyond simply identifying what key human rights concerns existed, to also identify who was accountable in law for improving those situations, allowing the Commission and others to later explore how this could be realized, for 
example, through a National Action Plan. The Commission therefore set about to operationalize these principles through adopting what it has called a FAIR framework.

F - Draw out a full understanding of the Facts (primary \& secondary research) A - Analyze what human rights are at stake (human rights analysis of all data) I - Identify what needs to be done and who has the responsibility for doing it (participative exploration of responsibility by rights-holders and duty-bearers)

$\mathbf{R}$-Recommendations for change and Recall to ensure change is happening (participative process engaging rights-holders and duty-bearers). ${ }^{50}$

Using the FAIR framework in collating the evidence-base allowed the Commission to develop a shared understanding of the nature of the problems in Scotland and their potential solution/s as well as provide a common framework of exploration and analysis for a diverse range of methods.

\section{Research and Analysis Methods}

\section{Historical mapping to engineer space to negotiate rights violations}

The research to develop the evidence-base began in 2009 with a series of workshops with key experts from academia, civil society, public bodies and experts by experience. These workshops enabled the various experts to interrogate a draft plan of methods for this work from which the Commission was able to refine its plan. A Research Advisory Group was also drawn from the participants to help guide all of the research work undertaken by the Commission. The outcome was a plan of research that was divided into three key phases of work as set out in Table 1 below. 


\begin{tabular}{|c|c|}
\hline $\begin{array}{l}\text { Phase } 1 \\
\text { Data } \\
\text { Collection } \\
\text { Activities } \\
\text { (2010) }\end{array}$ & $\begin{array}{l}\text { Annotated Bibliography of publish \& grey social science literature } \\
\text { (2006-2010) (Commissioned project: (Driver et al.,2010) } \\
\text { Three legal literature reviews exploring specific Conventions/Acts in } \\
\text { relation to the law in Scotland (ICESCR, HRA/ECHR \& CAT) (2006- } \\
\text { 2010) (Commissioned projects: (Smith etc et al., } 2010^{52} \text {, Normand and } \\
\text { Webster, 2010 } \\
\text { Compilation of all indivinidual enquiries received by the Commission and } \\
\text { all general intelligence on systemic human rights issues in Scotland } \\
\text { collated by the Commission (2008-2010) (In-house project) } \\
\text { Compilation of the Commission's National Consultation responses } \\
\text { (SHRC, 2009a) } \\
\text { Preliminary Scotland data from the Human Rights Measurement } \\
\text { Framework: (Candler et al., 2011) }{ }^{56} \text {. (In-house project) }\end{array}$ \\
\hline $\begin{array}{l}\text { Phase } 1 \\
\text { Activity }\end{array}$ & $\begin{array}{l}\text { Development of a 3rd sector stakeholder database of organisations } \\
\text { across Scotland (particularly local and community level groups) who } \\
\text { did human rights work (even if they didn't realize they did). }\end{array}$ \\
\hline $\begin{array}{l}\text { Phase } 1 \\
\text { Activity }\end{array}$ & $\begin{array}{l}\text { Human Rights Analysis : Code each source by any HRA or ICESCR } \\
\text { Article engaged } \\
\text { (In-house project) }\end{array}$ \\
\hline $\begin{array}{l}\text { Phase } 1 \\
\text { Output }\end{array}$ & List of issues under each Article of the HRA and ICESCR \\
\hline $\begin{array}{l}\text { Phase } 1 \\
\text { Activity }\end{array}$ & $\begin{array}{l}\text { Review all issues under each Article of HRA and ICESCR to draw out } \\
\text { core themes } \\
\text { (In-house project) }\end{array}$ \\
\hline $\begin{array}{l}\text { Phase } 1 \\
\text { Output }\end{array}$ & A Contextual and Thematic Framework for Phase 2 \\
\hline $\begin{array}{l}\text { Phase } 1 \\
\text { Activity }\end{array}$ & $\begin{array}{l}\text { Development of Six Contextual and Eight Thematic Areas of Focus. } \\
\text { Application of Prioritization Criteria to each individual issue raised } \\
\text { from the Phase } 1 \text { data within each of the six Contextual and eight } \\
\text { Thematic Areas } \\
\text { (In-house project) }\end{array}$ \\
\hline $\begin{array}{l}\text { Phase } 1 \\
\text { Output }\end{array}$ & $\begin{array}{l}\text { Six Contextual \& Eight Thematic Areas of Focus and the Priority Issues } \\
\text { within each area to be explore in more detail in Phase } 2 \text { of the project. }\end{array}$ \\
\hline $\begin{array}{l}\text { Phase } 2 \\
\text { Activity } \\
(\mathbf{2 0 1 0}-11)\end{array}$ & $\begin{array}{l}\text { Focus groups \& interviews } \\
106 \text { people participated in one of } 13 \text { focus groups or } 11 \text { in-depth } \\
\text { interviews across a wide span of geographical areas of Scotland. } \\
\text { Participants were purposively selected via a sampling framework } \\
\text { created from the Commission Stakeholder database (Phase 1) } \\
\text { (In-house project) }\end{array}$ \\
\hline $\begin{array}{l}\text { Phase } 2 \\
\text { Output }\end{array}$ & Transcripts and working notes (In-house project) \\
\hline $\begin{array}{l}\text { Phase } 2 \\
\text { Activity }\end{array}$ & $\begin{array}{l}\text { Human rights analysis } \\
\text { (In-house project) }\end{array}$ \\
\hline $\begin{array}{l}\text { Phase } 2 \\
\text { Output }\end{array}$ & $\begin{array}{l}\text { Draft Thematic \& Contextual Chapters } \\
\text { (In-house project with RA support) }\end{array}$ \\
\hline $\begin{array}{l}\text { Phase } 2 \\
\text { Activity }\end{array}$ & $\begin{array}{l}\text { Review of all outstanding UN treaty body recommendations \& } \\
\text { obligations relevant to Scotland within the Thematic \& Contextual } \\
\text { chapters (Commissioned project) }\end{array}$ \\
\hline
\end{tabular}




\begin{tabular}{|c|c|}
\hline $\begin{array}{l}\text { Phase } 2 \\
\text { Output }\end{array}$ & Redrafted chapters (In-house project) \\
\hline $\begin{array}{l}\text { Phase } 2 \\
\text { Activity }\end{array}$ & Academic \& Practitioner peer review \\
\hline $\begin{array}{l}\text { Phase } 2 \\
\text { Output }\end{array}$ & $\begin{array}{l}\text { Launch of evidence base report Getting it Right? Human rights is } \\
\text { Scotland on October 30th } 2012 \text { (In-house project) }\end{array}$ \\
\hline $\begin{array}{l}\text { Phase } 3 \\
\text { Activity } \\
\text { (2012-13) }\end{array}$ & $\begin{array}{l}\text { Launch of a } 5 \text { month participative review of GIR? To ask two } \\
\text { questions: } \\
\text { 1. Did GiR? reflect lived experience? } \\
\text { 2. What action/s was/were required for change and who held } \\
\text { responsibility to realize that change? } \\
\text { (In-house project) }\end{array}$ \\
\hline $\begin{array}{l}\text { Phase } 3 \\
\text { Activity } \\
\text { Methods }\end{array}$ & $\begin{array}{l}\text { An online/postal/phone questionnaire } \\
\text { A national interaction on } 10 \text { December } 2012 \text { which brought together } \\
\text { over } 80 \text { individuals representing a wide range of public, private, 3rd } \\
\text { sector organisations and experts by experience. } \\
\text { an online webcast to enable people living in remote and rural areas to } \\
\text { directly engage and contribute their views } \\
\text { a whole day event with Glasgow Caledonian University } \\
\text { three events at The Gathering } 2013 \text { (Scotland's biggest third sector } \\
\text { event) } \\
\text { a fringe meeting at the Scottish Trade Union Congress } \\
\text { a student-focused event at the University of Edinburgh } \\
\text { Participation groups were also established in partnership with a range of } \\
\text { civil society organisations }{ }^{57} \text { and five focus groups facilitated. } \\
\text { (In-house projects with partnership working) }\end{array}$ \\
\hline $\begin{array}{l}\text { Phase } 3 \\
\text { Outputs }\end{array}$ & $\begin{array}{l}\text { Participation from } 430 \text { people at various events produced } 20 \text { collective } \\
\text { response reports. } \\
\text { A further } 124 \text { written contributions were received including } 64 \\
\text { individual responses and } 60 \text { organizational responses. } \\
\text { In total } 144 \text { responses were received. }\end{array}$ \\
\hline $\begin{array}{l}\text { Phase } 3 \\
\text { Activity }\end{array}$ & $\begin{array}{l}\text { Analysis of participative consultation responses } \\
\text { (In-house project) }\end{array}$ \\
\hline $\begin{array}{l}\text { Phase } 3 \\
\text { Output }\end{array}$ & $\begin{array}{l}\text { Participative Consultation Report } \\
\text { (In-house project) }\end{array}$ \\
\hline $\begin{array}{l}\text { Final } \\
\text { Output } \\
(\mathbf{2 0 1 3 )}\end{array}$ & $\begin{array}{l}\text { Evidence base: Getting it Right? \& Participative Consultation } \\
\text { Reports }\end{array}$ \\
\hline
\end{tabular}

As can be seen in the detailed table above, the first phase of the project involved the collation and analysis of a range of secondary data. The vast majority of this data (annotated bibliography; legal literature reviews; individual enquiries and Commission intelligence; and the responses to the Commission's National Consultation) was 
qualitative in nature, with only the preliminary statistical data from the HRMF indicators providing a level of nationally aggregated data.

Each of the Phase 1 sources was analyzed through a human rights lens in order to: draw out the potential human rights concerns that existed across Scotland; identify which specific rights these issues engaged with and to develop a thematic framework through which to view these concerns. From this process, the Commission was able to draw out a wide range of issues of current concern in Scotland, which had the potential to impact on the realisation of civil, political, economic, social and cultural rights. The framework developed to house all of these issues consisted of: six contextual areas of focus (Political, Economic, Social, Technological, Legal and Environmental), which allowed for the presentation of the context within which the people of Scotland live their lives and can realize (or not) their rights on a daily basis, and eight broad thematic areas (Dignity \& Care; Health; Where We Live; Education \& Work; Private \& Family life; Safety \& Security; Living in Detention; Access to Justice \& the Right to an Effective Remedy). Developing outputs (Table 1) at each stage permitted all experts the opportunity to shape future stages thus ensuring the process was participatory and outputs were informed by all. ${ }^{59}$ This strategy worked well where not all spaces (all Activities) could be equally shared by all the experts.

The main aim of Phase 2 was to test the findings from the phase 1 analysis, with a series of small focus groups and in-depth interviews with an illustrative sample of people with lived experience of human rights violations. In taking this approach, SHRC sought to put a 'human face' on the issues uncovered in Phase 1 of the project. 
The focus group and interview schedules were semi-structured to allow for a degree of comparison across all focus groups and interviews, whilst at the same time allowing for discussions to develop in areas of importance to each group/individual. The schedules were developed and validated via a pilot study, following which each tool was refined. The proposed approach for Phase 2 of the research was also approved for ethics and reviewed at various stages by the Commission's Independent Research Advisory Group.

In total, 106 people participated in one of 13 focus groups or 11 in-depth interviews across Scotland. The various groups involved were purposively selected to participate in this project. In order to make this selection, a sampling framework was first created from the Commission's Stakeholder database. All groups within the database were coded by the thematic area/s of focus. ${ }^{60}$ The aim was to conduct at least one focus group where participants had a particular experience or expertise in each of the eight thematic areas.

These sessions explored how people, in different geographical areas of Scotland, with different life experiences and different understanding of their rights, felt about human rights issues in Scotland, in their communities and in their day-to-day lives. The sessions explored a number of key questions including a focus on which human rights issues were of most concern to people in the context of their lives, their communities and Scotland as a whole. The transcripts, recorded with the permission of participants, were then coded and analyzed using the contextual and thematic framework which emerged from Phase $1 .{ }^{61}$ 
The final source of data that was collated and analyzed for the evidence base was a record all of the outstanding UN treaty body recommendations \& obligations with relevance to Scotland. This was facilitated by the availability of the UN web-portal database $^{62}$ which provides easy access to country-specific human rights information originating from international human rights mechanisms in the United Nations system (e.g. the Treaty Bodies, the Special Procedures and the Universal Periodic Review (UPR)). The decision to explore what the UN Treaty Mechanisms considered to be the key human rights issues in Scotland at the end of the project, rather than at the start, was a conscious one. The reason behind the decision was two-fold. The first, stemmed from the complex nature of Scotland and its devolved status within the UK. The UK is the State which is held accountable at Treaty Body reviews and whilst the visibility of Scotland, as a country with a distinct legal system and many areas of devolved competency is improving, the complexity is not always well understood by Committee Members. As such, it is only in recent years where specific recommendations for the Scottish Government have appeared within the Treaty Body recommendations. The second reason was to ensure that the research was not limited in scope to those issues that had so far made their way to the awareness of the Treaty Bodies.

The launch of the Commission's report Getting it Right? Human Rights in Scotland in $2012^{63}$ was not seen as a definitive view about the state of human rights in Scotland, rather it was viewed as the start of a conversation with rights-holders and duty-bearers. The Commission shared its findings and asked people to reflect on two key questions: First, did Getting it Right? get it right?, did it highlight the key concerns in Scotland and reflect people's lived experience? And second, what action/s was/were required for change and who held responsibility to realize that change? 
The participative review of Getting it Right? lasted five months utilizing a range of methods to collect the data, including: a questionnaire (online/postal/phone); a national interaction; an online webcast; public meetings and a range of participative sessions with marginalised groups. The overall finding of the participative review was that for the most part Getting it Right? did reflect the lived experience of people in Scotland, with many respondents reinforcing the evidence already collected. There were, however, criticisms about the absence of some particular issues, most notably a specific focus on human rights education and the concerns of Kinship carers within the research evidence on the rights of unpaid carers. It was also criticized for not presenting evidence overtly from a gendered perspective. All of these issues and others and a wider analysis were then presented in a second report published in the summer of 2013.

The overall evidence base, therefore, is contained within these two reports: Getting it Right? (2012) $)^{64}$ and the Participative Consultation Report (2013). ${ }^{65}$

\section{Thematic measures versus indicators}

\section{The challenges \& limitations}

One of the primary challenges faced at the outset of this project, which will be familiar to many considering such a project, was brought about by the constraints of time and resource. At the initial expert advisory meetings the Commission presented its ideas on what this project could entail, it quickly became apparent that the project as it was presented then was overambitious and unachievable. ${ }^{66}$ The Scottish Human Rights Commission has ten staff, one of whom dedicated approximately 60 per cent time to this project over the three years and others dedicated significant periods at moments 
required. During this time the Commission was also faced with a reducing budget of (19 per cent in real terms) and had to devote the majority of its research budget to this project over the three years in order to make the evidence base realizable. Dictated by budget, the aim of the project had to be a modest one, it was to gain a broad, illustrative understanding of the key human rights issues in Scotland today, providing the Commission and others with a baseline from which to build their work plan.

Many of the over ambitious elements involved more participatory research methods and the practical reality is that participatory work is time intensive. Empowerment and participation are, however, fundamental principles of a human rights based approach and as such, it was imperative that they were embedded into the research process. The compromise involved the wider range of secondary data sources combined with the primary data collected via a limited number of focus groups and interviews as presented above, alongside the participative review process following publication.

This combination of methods was important because self-reported data (i.e. what the Commission was told by members of the focus groups and those who participated in interviews) cannot be independently verified. What is included reflects an accurate record of the views of individuals on their perceptions - the Commission could not take responsibility for, nor claim, the veracity of those views. Indeed, self-reported data is believed to have a number of limitations including, social desirability, selective memory and exaggeration. However, the supposed poor quality of self-reported data is now commonly regarded as an "urban myth' ${ }^{97}$ and numerous self-report measures in the field of social science (and medicine) have achieved acceptance. Accordingly, in this project, utilizing a number of different types of information and methods of collecting 
that information, and subjecting them to a process of triangulation, allowed for a degree of validation of the findings. In other words the fact that the same issues of concern were being raised within the different secondary sources, as well as the focus groups and interviews, strengthens our confidence in the accuracy of the findings of this project.

A further limitation arose as a result of the limitation of the reviews of both the legal and social research literature themselves. In respect of the legal literature review, it was found that there was very limited legal literature on a wide range of issues which have been central to the experience of the Commission since its inception - such as dignity and care - and a relatively large volume of legal literature in respect of a small portion of the human rights spectrum - notably human rights in criminal justice settings. Many human rights researchers and practitioners have been:

Slow to address issues of class, poverty, inequality and social and economic injustice, instead focusing mainly on civil and political rights. ${ }^{68}$

Equally, the reviews of social science research and literature revealed that very little social research had in fact been undertaken or written about from a human rights perspective. Indeed, social scientists historically have been reluctant to engage with human rights. Within the social science research and literature reviewed, there was a strong focus on equality as the principle driver of social progress. However:

Whilst there is a strong relationship between equality and human rights, they are not the same, and their conflation can risk marginalizing the importance of other constituent concepts within human rights such as dignity, respect, diversity and autonomy. ${ }^{69}$ 
Social policy has been criticised for failing to suggest the means by which social problems might be reduced or eliminated, as Dean ${ }^{70}$ notes:

If Social Policy must struggle to understand what's wrong with society and with existing policies, it must also consider the various ways in which these may be put right. $^{71}$

Potentially, one of the biggest challenges presented by this project is the speed at which the literature and evidence becomes dated. At the time of writing, the Commission has had to commit resources for external research support to update sections of the evidence base in order to have access to the most current data for two Treaty Body reviews taking place in 2016. Getting it Right? took three years to create and although modest in research budget terms, the same resources will not be available again, neither will the time taken. Repeating a project of this scale will not be feasible, however, the evidence base has provided an invaluable source of data both for the Commission and the $3^{\text {rd }}$ sector and the Commission is therefore reflecting on how best to do this.

The Office of the High Commissioner for Human Rights (OHCHR) provide good templates to monitor human rights at the national level which they recommend should be tailored to a given national context. Recognizing the many challenges a country may face in producing such evidence bases, the OHCHR has invested considerable efforts in the development of human rights based indicators, to support the creation of national human rights measurement frameworks, the conceptual value over which there has been international agreement, in recent years. ${ }^{72}$ The UN guidance also supports the use of both qualitative and quantitative evidence to enable the highlighting of widespread human rights violations on the one hand, but also allow for the identification of 
potentially hidden violations against smaller marginalised people or groups. However, a key difficulty in making use of this excellent work in the Scottish context is because it takes a Right by Right approach. The framework analysis that emerged from Getting it Right? was thematically based to allow fluidity, to help intersectional issues emerge, and to avoid a hierarchy of rights emerging.

\section{The advantages}

One of the challenges as noted above, was the difficulty presented by resource constraints, in particular the necessity to curb some of the more ambitious research methods. However, it is also critical to recognize the value of participative methods in the research process that goes beyond simply doing good research. The relationships that developed between the then, very young Commission and a wide range of marginalised communities, as well as key stakeholders from the $3^{\text {rd }}$ sector, public bodies and the Scottish government, have been of immeasurable value in the development and implementation of Scotland's first National Action Plan for Human Rights. The time invested in developing these relationships during the research process is believed to be a key reason behind the strong collaborative partnerships and the development of a genuinely participative development of a National Action Plan.

Another of the challenges noted above, related to the current limitations of both social science and legal literature. Therefore, one of the values of this research comes from the way in which it is combined social policy, social science and legal research with human rights standards in this project. In order to better understand the current state of human rights realisation in Scotland, the Commission had to take an innovative step to expand the work of both research sectors. By encouraging both research sectors to take 
steps beyond their traditional disciplinary boundaries should over time, help to contribute to the promotion and protection of human rights in Scotland.

The Phase 2 research also demonstrated the gap that exists between what people experience in their day-to-day lives, the language they use to describe it, and human rights discourses. This is an ongoing issue, however, this type of research has in part contributed to bridging that gap. For people to be empowered to realize their rights, they first need to understand what their rights are. As such, this type of research can be used as a method of empowerment through the research process itself.

The annotated bibliography highlighted that much academic research currently does not identify a duty-bearer, indeed, this was the case for 46 per cent of all literature. A human rights lens always seeks to identify who is responsible for change and what action is required and therefore, one of the advantages of applying a human rights analytical lens to this work has been the ability to rethink social problems and solutions to common social policy concerns.

In the challenges noted above the issue raised by the thematic approach taken in this research was noted. There are, however, some key advantages in taking this approach. First, as already noted, the evidence based revealed a widespread lack of knowledge about human rights, especially in relation to economic, social and cultural rights. It also revealed that many $3^{\text {rd }}$ sector organisations don't currently frame their campaigns or issues from a human rights perspective as they don't see the value in this approach and or don't make the connections to their issues. The thematic approach of Getting it 
Right? has helped to bridge some of those knowledge gaps, with more organisations now expression an interest and ability to make those connections.

Second, this is also how the Scottish Government approaches its own work through the National Performance Framework (NPF) ${ }^{73}$ Therefore, in order to support the Scottish Government to embed human rights indicators within their NFP (which it is doing at the time of writing) the Commission needs to be able to present key human rights concerns in the same thematic framework as the Government works on a day-to-day basis.

\section{Conclusion}

It cannot be argued strongly enough, that reform around rights realizations will only happen if the State and Duty Bearers are committed to this change. Further, ring-fenced resources, critical to trigger a cultural shift, ${ }^{74}$ ideally should be available and extensive to fully engage in producing a participatory baseline.

Achieving participative working also needs a commitment from Duty Bearers at a philosophical level. They should be prepared to provide the space and time required to permit learning from outside of their focused fields. Without this, a meaningful discourse with Rights Holders and the experienced experts will be limited, and so will progress. This may also require a shift in discourses used, away from elaborative language, or heavy use of acronyms, to rhetorical language. ${ }^{75}$

If these conditions are nurtured, then it is argued that this collaborative, participatory qualitative process is much stronger than indicators, in realising rights. Firstly because the reform/change is built into the process, it is produced at the time that violations are shared. Secondly because a hidden voice that needs change, is revealed through the marginalised experiences of rights holders. This isn't lost through the data corruption 
that occurs as indicators reduce experience, rather experience remains contextualised. And finally, rich experience is heard directly by those with the power and resources to trigger change, by those who are accountable.

Scotland is in the process now of maintaining these spaces of negotiation and the challenge of measuring a qualitative process in a way that allows progress to be evidenced. Though still a 'work in progress', there is much to learn about the investment required to realise rights across a nation. 
Acknowledgements: With thanks to the Scottish Human Rights Commission and the teams across Scotland that have contributed to SNAP and shared the process with the authors.

\section{References}

${ }^{1}$ SNAP Scottish National Action Plan http://www.snaprights.info/

See also, Hosie, A. and Hutton, E. (2015) The contribution of national action plans for human rights to the pursuit of equality and social justice: lessons from Scotland. Beyond 2015: Shaping the Future of Equality, Human Rights and Social Justice. A Collection of Essays from the Equality and Diversity Forum and EDF Research Network.

${ }^{2}$ FAIR: F - Facts: What are the important facts to understand?

A - Analysis: What are the human rights or issues at stake?

I - Identifying Shared Responsibilities: What changes are necessary? Who has responsibilities for helping to make the necessary changes?

$\mathrm{R}$ - Recall: Over time have the necessary changes occurred? If not, who is to be held accountable?

Using the FAIR methodological framework throughout this programme of work has allowed SHRC to identify the facts and provide a common framework for exploration and analysis.

${ }^{3} \mathrm{OHCHR}$ human rights based indicator methodology allows for three types of human rights indicators, namely: structural, process and outcome indicators. Together they address the essential aspects of human rights implementation, namely: commitment, effort and result. See Office of the High Commissioner for Human Rights (OHCHR) Human Rights Indicators: A Guide to Measurement and Implementation; OHCHR Guide, a Human Rights Measurement Framework http://www.ohchr.org/EN/Issues/Indicators/Pages/documents.aspx

${ }^{4}$ Merry, S. E. (2016) A World of Quantification: Measuring Human Rights, Gender Violence and Sex Trafficking Chicago: The University of Chicago Press Page 10

${ }^{5}$ Maurer, B. (2005) Mutual Life, Limited: Islamic Banking, Alternative Currencies, Lateral Reason. Princeton, NJ: Princeton University Press

${ }^{6}$ Trubek, D. M. \& Trubek, L. G. (2005) Hard and Soft Law in the Construction of Social Europe: the Role of the Open Method of Co-ordination. European Law Journal Vol. 11 (3) May 2005 343-364

${ }^{7}$ Landman (2009) Measuring Human Rights Oxon: Routledge Page. 137

${ }^{8}$ Merry A World of Quantification 2016:13

${ }^{9}$ see Espeland, W. N. \& Stevens, M. L. (2008) ‘A Sociology of Quanitfication' European Journal of Sociology Vol 49(3): 4-1-36

${ }^{10}$ Bowker, G. C. \& Star, S. L. (1999) Sorting Things Out: Classification and Its Consequences. Cambridge, MA: MIT Press

${ }^{11}$ For example the UK Census measures household data every 10 years and aims to capture the entire population. Gender has traditionally been reduced to only two categories making it synonymous to the bi-categorization of sex.

12 see Foucault, M. (1979) Discipline and Punish: The Birth of the Prison. New York: Vintage.

${ }^{13}$ Power, M. (2004) 'Counting, Control and Calculation: Reflections on Measuring and

Management. Human Relations. Vol. 57 (6): 765-83

${ }^{14}$ Merry World of Quantification 2016

${ }^{15}$ Ibid., 33

${ }^{16}$ Ibid. 
${ }^{17}$ US Department of State(2016) Trafficking in Persons Report. Washington, DC: US Department of State

Example of graph on page 19 (2016) Reports from 2001-2016 inclusive available: https://www.state.gov/j/tip/rls/tiprpt/

${ }^{18}$ Merry World of Quantification 2016

${ }^{19}$ Latour, B. (1987) Science in Action: How to Follow Scientists and Engineers through

Society. Cambridge, MA: Harvard University Press.

${ }^{20}$ McNulty, D., Watson, N., and Philo, G. (2014) Human rights and prisoners' rights: the British press and the shaping of public debate. Howard Journal of Criminal Justice, 53(4), pp. 360376

${ }^{21}$ Latour Science in Action 1987

${ }^{22}$ Ibid., 57-58

${ }^{23}$ Dean (2007) FULL REFERENCE NEEDED

${ }^{24}$ The Sociological Cannon of Karl Marx, Emile Durkheim and Max Weber has been criticised for over-representing dead white men. They group include a disabled man and a migrant so they may not be as privileged and mainstream as they first appear. Nevertheless, their theorising, while enormously influential to contemporary social scientists, has limited use for understanding Rights.

${ }^{25}$ Walby, S. (1994) Is citizenship gendered? Sociology Vol 28 (2) 379-395

${ }^{26}$ Fraser, N. and Honneth, A. (2004) Redistribution or Recognition?: A political-philosophical exchange. Verso Press

${ }^{27}$ Nussbaum, M. (2006) Frontiers of Justice; Disability, Nationality, Species Membership The Tanner Lectures on Human Values Cambridge, MA and London: The Belknap Press

${ }^{28}$ Rawls wrote about 'eligibility for citizenship': the social contract theory throughout his career, but notable references include: J. Rawls, A Theory of Justice (Cambridge, MA: Harvard University Press, 1971); and J. Rawls, 'Kantian Constructivism in Moral Theory' (Dewey Lectures), Journal of Philosophy 77 (1980): 515-71.

${ }^{29}$ see Ferrie, J. (2010) What has Human Rights got to say about Care and Dignity? International Journal of Human Rights - Special Issue: Sociology and Human Rights Vol. 14 (6) November 2010

${ }^{30}$ Walby, S. (2009) Globalization \& Inequalities: complexity and contested modernities. London: Sage Publications.

${ }^{31}$ Burchardt, T. and Vizard, P. (2007) Definition of equality and framework for measurement: Final Recommendations of the Equalities Review Steering Group in Measurement, CASE Paper 120, London School of Economics

${ }^{32}$ Walby Globalization \& Inequalities 2009

33 Hosie, A. and Lamb, M. (2013) Human rights and social policy: Challenges and opportunities for social research and its use as evidence in the protection and promotion of human rights in Scotland. Social Policy and Society. Vol. 12 (2) pp 191-203

${ }^{34}$ Walby Globalization \& Inequalities 2009

${ }^{35}$ Burchardt, and Vizard, P. Framework for equality and framework for measurement. 2007

${ }^{36}$ Townsend, (1975)

${ }^{37}$ Dean, H. (2006) Social Policy, Cambridge: Polity Press.

${ }^{38}$ See Boyle \& Hughes, this special edition.

${ }^{39}$ Ferrie, J. \& Watson, N (2015) The psycho-social impact of impairment: the case of Motor Neurone Disease Editor: Shakespeare, T. Disability Research Reader, Routledge

${ }^{40}$ Simon, W. H. (2004) 'Toyota Jurisprudence: Legal Theory and rolling Rule Regimes' in Columbia Public Law and Legal Theory Working papers. Working paper 0479.

http://lsr.nellco.org/colunbia_pllt/0479

${ }^{41}$ Ibid.

${ }^{42}$ For a general overview of the approach, see Dick, B. (2014) Action Research In. Mills, J. and Birks, M. (Eds.) Qualitative Methodology: A Practical Guide. London: Sage. 
For a classic example of this approach in action, see Freire, P. (1972) Pedagogy of the Oppressed. London: Penguin Books.

${ }^{43}$ Merry World of Quantification 2016

${ }^{44}$ Erturk, Y. (2008) 'Report of the Specia Rapporteur on Violence against Women, Its Causes and Consequences, the Next Step: Developing Transnational Indicators on Violence against Women' (addendum). In Promotion and Protection of all Human Rights, Civil, Politial, Economic, Social and Cultural, Including the Right to Development. Human Rigts Council, 7th Session February 25. A/HRC/7/6/Add.5.

${ }^{45}$ Office of the High Commissioner for Human Rights (OHCHR) Human Rights Indicators: A Guide to Measurement and Implementation; OHCHR Guide, a Human Rights Measurement Framework http://www.equalityhumanrights.com/human-rights/our-human-rightswork/human-rights-measurement-framework/

${ }^{46}$ Universal Declaration of Human Rights, Articles 1-5 and 16

${ }^{47} \mathrm{http}: / /$ www.legislation.gov.uk/asp/2006/16/pdfs/asp_20060016_en.pdf

${ }^{48} \mathrm{http}: / /$ www.ohchr.org/EN/ProfessionalInterest/Pages/Vienna.aspx

${ }^{49} \mathrm{http} / / / \mathrm{www} . \mathrm{scottishhumanrights.com/about/strategicplan/strategicplan20082012}$

${ }^{50}$ FAIR framework see footnote ii

${ }^{51}$ Driver, S., Lamb, M. \& Wislon, C. 2010. Annotated Bibliography of Published and Grey Non-Legal Literature on Human Rights in Scotland since 2006. London: The Crucible Centre and Social Research Centre, Roehampton University.

${ }^{52}$ Smith, R., Tait, L., Bales, K., McConnell, L. \& Raban-Williams, R. 2010b. Mapping the Law of Scotland in Relation to International Human Rights Treaties: CAT \& CPT. Newcastle:

Northumbria Law School.

${ }^{53}$ Normand, A. \& Webster, E. 2010. Mapping the Law of Scotland in relation to International Human Rights Treaties - Civil and Political Rights. Glasgow: University of Strathclyde.

${ }^{54}$ Flanigan, D. 2011. Mapping the Law of Scotland in Relation to Economic, Social \& Cultural Rights. Glasgow: Scottish Human Rights Commission.

${ }^{55}$ SHRC 2009. Building a Strategic Plan: Consultation Report. Glasgow: Scottish Human Rights Commission.

${ }^{56}$ Candler, J., Holder, H., Hosali, S., Payne, A., Tsang, T. \& Vizard, P. 2011. Human Rights Measurement Framework: Prototype panels, indicator set and evidence base. London: LSE, CASE, BiHR, SHRC, EHRC.

57 The groups were developed in partnership with Article 12 and the Scottish Gypsy /Traveller Law Reform Coalition, the Coalition for Racial Equality and Rights, Glasgow Disability Alliance, Inclusion Scotland and Voices of Experience, the Poverty Truth Commission and the Scottish Consortium for Learning Disability.

${ }^{58}$ Some of the responses from organisations drew on their own consultation and outreach experiences, for example the response from the Scottish Youth Parliament reflected the policy priorities identified in their own consultation that gathered the views of 42,804 young people.

${ }^{59}$ Dick, B. Action Research 2014

${ }^{60}$ Twenty-four groups were selected from which 17 groups agreed to participate. Some groups contained individuals who preferred to be interviewed on a one-to-one basis than participate in a focus group.

${ }^{61}$ This process was facilitated by the use of the qualitative analysis software NVivo, which allows for thematic coding and the integration of focused inquiry and data analysis. As the Phase 1 data had already been coded into NVivo, the process of combining the analysis of Phase 1 and Phase 2 data was relatively simple.

${ }^{62}$ See http://uhri.ohchr.org/

${ }^{63}$ SHRC (2012) Getting it Right? Human Rights in Scotland. See http://www.snaprights.info/how-snap-was-developed/getting-it-right

${ }^{64}$ Ibid. 
${ }^{65}$ SHRC (2013) Participative Consultation Report. See http://www.snaprights.info/how-snapwas-developed/participation

${ }^{66}$ The initial project plans involved a further range of participative methods including a photography competition and a national diary day.

${ }^{67}$ Chan (2009)

${ }^{68}$ Hosie, A. and Lamb, M. (2012) Hosie, A. and Lamb, M. (2013) Human rights and social policy: Challenges and opportunities for social research and its use as evidence in the protection and promotion of human rights in Scotland. Social Policy and Society. Vol. 12 (2) pp192

${ }^{69}$ Ibid.

${ }^{70}$ Dean, (2006)

${ }^{71}$ Ibid., 101

${ }^{72}$ Office of the High Commissioner for Human Rights (OHCHR) Human Rights Indicators: A Guide to Measurement and Implementation; OHCHR Guide, a Human Rights Measurement Framework http://www.equalityhumanrights.com/human-rights/our-human-rightswork/human-rights-measurement-framework/.

${ }^{73}$ Explain NPF

${ }^{74}$ Ferrie, J., Lerpiniere, J., Paterson, K., Pearson, C. Stalker, K. and Watson, N. (2008) In-Depth Examination of the Implementation of the Disability Equality Duty in England: Report to the Office for Disability Issues. London: Department for Work and Pensions.

See also: Pearson, C., Watson, N., Stalker, K., Ferrie, J., Lepiniere, J. \& Paterson, K. (2011) 'Mainstreaming the Disability Equality Duty and the impact on public authorities'. Social Policy and Society, 10(2).

${ }^{75}$ see Webster, E. and Flanigan, D. This Issue. 